\title{
Greeting Our 20th Year
}

\author{
By Kiyohisa Fujino*
}

\author{
President of TMSJ
}

The Textile Machinery Society of Japan maked its 20th year with a celebration program from May 26 to 27 .

The Society was brought into being in June 1948 amid the chaos and poverty of the early postwar years. Our founding fathers were men in the textile and textile machinery industries and related research fields who sought to help in speedy reconstruction and future expansion of Japanese industry. Our Society, therefore, symbolized inseparable relations between the two industries and research fields.

The Society is essentially an accademic organization devoted to cotribution to the advancement of knowledge and technique in the textile and textile machinery fields. Its membership comprises universities, research institutes, textile manufacturers, textile machinery manufacturers, business firms with textile and/or textile machinery department, or individuals of expert knowledge and experience connected with these organizations.

As part of its work, the Society started the Journal of the Textile Machinery Society of Japan, which has been published manthly (Japanese edition) without interruption from the very beginning.

Its maiden issue, dated September 1948, was inavoidably limited to 54 pages printed on poor-quality paper. This reminds us of the acute shortages of printing paper at that time.

The Society has grown steadily with the years, its membership has increased, and its activities have become increasingly deversified. Today the Society is definitely a member of the international community of scientific and technical organizations.

Technique and knowledge in areas related to textiles and textile machinery have progressed steadily. In fact, aided by the amazing development of science and technology throughout the world in recent years, they have made revolutionary strides.

Manufacturing facilities, manufacturing techniques and management systems in textile industries have been replaced with up-to-date facilities, techniques and systems which are radically new departures.

Such has been the case in research fields, too. The diversity of treatises contributed by our members, the production of new publications by our Society, its sponsoring of lectures, symposiums and seminars and educational tours of factories - these are some of the examples of the "up-to-date-ness" of research fields.

Our Society regularly announces the results of researches and experiments by members. This not only benefits the members concerned but contributes to developing science and technology, resulting in promotion of academic information exchange.

As part of its work, the Society publishes a bimontly journal in English to help in international exchange of knowledge. The English edition has brought forth large numbers of foreigh academic journals on an exchange basis. They impart useful new additions to the knowledge of our members

Let us not forget that our Society is unobtrusively engaged in many other activities, little known but highly important.

A great part of our Society's budget is accounted for by ordinary membership fees. They are, however, barely enough to finance the publication of The Journals of The Textile Machinery Society of Japan and a few other activities. Membership fees of the supporting members and advertising in our Jounnal, both Japanese and English editions, contribute in large measure to our financial up keep.

Therefore, our Society has to bear in mind the support it receives from industrial and business firms in sponsaring various programs. Yet it must uphold its prestige as an academic organ without being degmatic.

A high tribute is due to Dr. Risaburo Torikai, our first president, and Kojiro Abe, our second president, for their services to the Society. Acknowledgment is also due to the directors, particularly the managing directors, who often meet in conference in the Secretariat office to shape important policies.

In its 20 years, our Society has experienced social and economic difficulties. It is directly affected by industrial depressions because a large part of its membership comprises industrialists. Such difficulties have all been overcome with the superb judgement and able directions of the directors.

Our Society has many committees, each composed of "front-line" young research men. They are the 
nucleus of our everyday activities. We cannot thank them adequately for what they have done and are doing.

The Secretariat personnel of our Society are office workers and cannot be thought of in the same light as the directors and committees. However, they have the interests of the Society at heart just as the directors and committees do. I hope they realize that they belong to an organization different from a Government agency or a profit-making enterprise.

The Secretariat is indispensable to our Society. No work could be accomplished without its cooperation any more than any work can be accomplished by the
Secretariat alone. I must add that the Secretariat personnel are able people and I am grateful for their diligence and obligingness.

Being 20 years old means adulthood. I am afraid our Society has not yet grown up into a selfsupporting adult. I am not referring to its organizational scale or the size of its membership. What I mean is that it has still to grow into adulthood with firm foundations for high-level work.

"Great talents mature late," goes an old saying. Let us hope our Society will grow into full adulthood capable of worthy contributions to the technology, and industry it serves.

(* President of Fukui University, Fukui) 